Summer 2006

\title{
Religious Exemptions, Formal Neutrality, and Laïcité
}

Frederick Mark Gedicks

J. Reuben Clark Law School, Brigham Young University

Follow this and additional works at: https://www.repository.law.indiana.edu/ijgls

Part of the International Law Commons, and the Religion Law Commons

\section{Recommended Citation}

Gedicks, Frederick Mark (2006) "Religious Exemptions, Formal Neutrality, and Laïcité," Indiana Journal of Global Legal Studies: Vol. 13 : Iss. 2 , Article 6.

Available at: https://www.repository.law.indiana.edu/ijgls/vol13/iss2/6

This Symposium is brought to you for free and open access by the Law School Journals at Digital Repository @ Maurer Law. It has been accepted for inclusion in Indiana Journal of Global Legal Studies by an authorized editor of Digital Repository @ Maurer Law. For more information, please contact rvaughan@indiana.edu.

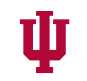

JEROME HALL LAW LIBRARY

$$
\begin{aligned}
& \text { INDIANA UNIVERSITY } \\
& \text { Maurer School of Law }
\end{aligned}
$$

Maurer School of Law
Blooming ton 


\title{
Religious Exemptions, Formal Neutrality, and Laïcité
}

\author{
Frederick Mark Gedicks*
}

\begin{abstract}
Rights to free exercise in the United States are governed by a doctrine of formal neutrality, which seems to resemble the French doctrine of laïcité. This resemblance tempts one to conclude that the doctrinal regimes of religious liberty in the United States and France are also essentially the same. Despite their superficial resemblance, howeve; formal neutrality and laïcité generate regimes of religious liberty that are substantially, even radically, different. Notwithstanding conceptually similar organizing principles, there is a significant difference in the substance of religious liberty in the United States and France owing to very different conceptions of the proper role of the state in securing religious freedom and other human rights. This difference is evident in the grammar that each country uses to describe free exercise rights, in their respective responses to the problem of religious and moral difference, and in their differing conceptions of equality adopted.
\end{abstract}

\section{INTRODUCTION}

The Free Exercise Clause of the First Amendment to the United States Constitution provides that neither the national government nor the states may enact a law "prohibiting the free exercise of religion." The precise meaning of this phrase has been highly contested, especially during the last half century. For much of that time, the Free Exercise Clause was interpreted by the Supreme Court to require that religious individuals and organizations be excused or "exempted" from complying with any law that interfered with their religious be-

*Professor of Law, J. Reuben Clark Law School, Brigham Young University, Provo, Utah; email: gedicksf@lawgate.byu.edu. I am grateful to Lee Andelin for research assistance.

1. The full text reads, "Congress shall make no law respecting an establishment of religion or prohibition the free exercise thereof." U.S. Const. amend. I. The first clause is known as the "Establishment Clause," and the second as the "Free Exercise Clause." Applicable only against the national government when they were initially ratified in 1791, both clauses were held applicable to the states in the 1940s. See Everson v. Bd. of Educ., 330 U.S. 1 (1947); Cantwell v. Connecticut, 310 U.S. $296(1940)$. 
liefs or practices, unless the government could identify an especially important regulatory interest that would be left unprotected by an exemption. ${ }^{2}$ In practice, the Court denied exemptions more often than it granted them, though the doctrine was more effective in lower courts and in administrative settings. Moreover, whatever its actual effectiveness in protecting religious freedom, the exemption doctrine stood for nearly three decades as a powerful symbol of the subordination of the state to religious belief and exercise.

The Supreme Court abandoned the exemption doctrine in 1990 in Employment Division v. Smith, holding that the Free Exercise Clause does not require that believers be excused from complying with a law that burdens their beliefs or practices, so long as the law is "religiously neutral" and "generally applicable."3 Religious neutrality and general applicability are terms of art that serve as important qualifiers to the general rule. ${ }^{4}$ Smith was hugely controversial when it was handed down, ${ }^{5}$ and it remains the target of much criticism. ${ }^{6}$ Although several of the justices have criticized Smith, ${ }^{7}$ the majority of the Court has given no indication that it is prepared to reconsider the decision, and after sixteen years, it appears to be here to stay.

Smith is usually understood to have imposed "formal neutrality" as a controlling principle on free exercise doctrine. Formal neutrality in the domain of religious freedom is a government stance that simply ignores the religious character of beliefs and practices for all government purposes. Philip Kurland described this posture as preventing government from using religion as a "standard for action or inaction," thus disabling government from using religion

2. Wisconsin v. Yoder, 406 U.S. 205 (1972); Frazee v. Ill. Dep't of Employment Sec. (Unemployment Compensation Cases), 489 U.S. 829 (1989); Hobbie v. Unemployment Appeals Comm'n, 480 U.S. 136 (1987); Thomas v. Review Bd., 450 U.S. 707 (1981); Sherbert v. Verner, 374 U.S. 398 (1963).

3. Employment Div. v. Smith, 494 U.S. 872 (1990).

4. See infra Part II.

5. See, e.g., James D. Gordon, III, Free Exercise on the Mountaintop, 79 CaL. L. Rev. 91 (1991); Douglas Laycock, The Remnants of Free Exercise, 1990 Sup. C. Rev. 1; Michael W. McConnell, Religious Freedom at a Crossroads, 59 U. CHr. L. Rev. 115 (1992).

6. See, e.g., Michael J. Perry, Freedom of Religion in the United States: Fin de Siècle Sketches, 75 IND. L.J. 295 (2000).

7. See City of Boerne v. Flores, 521 U.S. 507, 544-45 (1997) (O’Connor \& Breyer, JJ., dissenting); Church of the Lukumi Babalu Aye, Inc. v. City of Hialeah, 508 U.S. 520, 564 (1993) (Souter, $\mathrm{J}$., concurring in part and concurring in the judgment). 
or religious classifications "either to confer a benefit or to impose a burden." For example, a formally neutral ban on the sale and possession of alcohol, as once existed in the United States and still persists in some pockets of the rural South, ${ }^{9}$ would ban the use of wine to celebrate the mass. Providing an exemption for religious uses of wine would violate formal neutrality by expressly recognizing a class of believers and excusing them, as believers, from complying with the ban. Under a formally neutral regime, the fact that a ban on alcohol interferes with a religious rite is irrelevant, because the religious or nonreligious character of the use of alcohol is irrelevant. Formal neutrality treats everyone the same, believer and nonbeliever alike (though this is not, of course, necessarily the same as treating everyone equally or justly).

The meaning of the French doctrine of laïcité is something of a puzzle for Americans. Difficult to render in English, its meaning seems to resonate with a cluster of English terms, such as "secularism," the "separation of church and state," and, of course, "neutrality," including formal neutrality. The Academie Française, for example, defines laïcité as "the character of religious neutrality, independent with regard to all churches and confessions." ${ }^{10}$ Other authorities echo the sense of lä̈cité as state neutrality toward religion and religious belief, achieved and maintained by a rigorously secular administration of the government, the political system, and public life generally. ${ }^{11}$

8. Philip B. Kurland, Of Church and State and the Supreme Court, 29 U. CHI. L. Rev. 1, 96 (1961). Professor Laycock, who was a faculty colleague of Professor Kurland, cautions that Professor Kurland himself may not have understood his standard to be synonymous with formal neutrality, though it is so understood today. Douglas Laycock, Formal, Substantive, and Disaggregated Neutrality Touvard Religion, 39 DePAUL L. Rev. 993, 999 (1990).

9. Compare U.S. Const. amend. XVIII (prohibiting the "manufacture, sale, or transportation" of alcoholic beverages within the United States and its territories) with U.S. Consr. amend. XXI (repealing Amendment XVIII, but allowing states the option of prohibiting importation of alcoholic beverages).

10. Dictionnaire De L'Academie Française 7 (9th ed. 1992), available at http:/www.academiefrancaise.fr/dictionnaire/, translated in Holly Hinkley Lesan, The Muslim Foulard in France's Public Square: Current Conceptions of L'Ordre Publique, Laïcite, and Religious Liberty (May 8, 2004) (unpublished manuscript, on file with author).

11. See, e.g., Jean Baubérot, The Place of Religion in Public Life: The Lay Approach, in Facilitating Freedom of Relicion or Belief: A Deskbook 441, 441 (Tore Lindholm et al. eds., 2004) (Laïcité "signifies the absence of any official religion in a country, but also the absence of any official state atheism."); T. Jeremy Gunn, Religious Freedom and Laïcité: $A$ Comparison of the United States and France, 2004 BYU L. REV. 419, $420 \mathrm{n} .2$ (defining laïcité as a "political notion involving the separation of civil society and religious society, the State exercising no religious power and the churches... exercising no political power") (quoting 5 Le Grand RoberT de LA LANGUe Française 
The resonance between formal neutrality and lä̈cité tempts one to conclude that they are essentially the same. ${ }^{12}$ From this, it might follow that the doctrinal regimes of religious liberty in the United States and France are also essentially the same. Despite their superficial resemblance, however, formal neutrality and laïcité generate regimes of religious liberty that are substantially, even radically, different. I will suggest in this article that, notwithstanding conceptually similar organizing principles, there is a significant difference in the substance of religious liberty in the United States and in France owing to very different conceptions of the proper role of the state in securing religious freedom and other human rights. The conception of the good that informs American government is more procedural and less substantive than that which informs the French state. In Rawlsian terms, one could say that the United States has a much "thinner" theory of the good than does France. ${ }^{13}$ Whereas "religious freedom" in the United States typically suggests freedom of religion from state interference, in France laïcité often connotes the state's "protecting citizens from the excesses of religion,"14 and this makes all the difference.

A full-fledged defense of this thesis is beyond the scope of this article. What I hope to do is simply to illustrate it by providing three points of conceptual contact between French and American free exercise principles. The first point is grammatical, though nevertheless revealing--the syntax used by each country to inscribe protection of religious freedom in its basic laws. ${ }^{15}$ The remaining two points are more substantive-the differing ways in which the doctrine of religious freedom in both countries has responded to the problem of religious and moral difference in their respective societies, ${ }^{16}$ and the more formally egalitarian

915 (Alain Rey ed., 2d ed. 1992)); Lesan, supra note 10, at 12 ("Laïcité describes the [secular] character of the state rather than a right or freedom of its citizens."); Michel Troper, Religion and Constitutional Rights: French Secularism, or Laïcité, 21 CARDozo L. Rev. 1267, 1267 (2000) ("French secularism-or laïcité-is usually defined as a system in which there is a separation between religion and the state. That is to say, political and administrative powers are exercised by nonreligious authorities.").

12. See, e.g., Troper, supra note 11 , at 1267 (observing that the "United States is sometimes considered in France a laï state . . because in the United States the state is independent of any particular religion," but also noting that "[s]eparation is not ... a a appropriate translation of laïcite").

13. See John Rawls, A Theory of Justice $\$ \S 60-62$, at 395-407 (1971).

14. Gunn, supra note 11, at 420 n.2.

15. See infra Part I.

16. See infra Part II. 
quality of American free exercise doctrine in comparison to the French doctrine. $^{17}$

I should also emphasize that my purpose is descriptive, rather than normative. Although I think I prefer the approach of the United States, that is perhaps more a matter of habit than of analysis. There is much to recommend in both systems, which I will address in my conclusion. ${ }^{18}$

\section{Free Exercise Grammar in the United States and France}

Religious freedom guarantees in Europe follow a particular syntax. They usually state a general definition of the freedom of religion, and then describe activities that fall outside the definition of religious freedom, and circumstances under which government may properly limit that liberty. The European Convention for the Protection of Human Rights and Fundamental Freedoms (European Convention), for example, prescribes the right to "freedom of thought, conscience, and religion," and defines this right as encompassing the right to manifest one's beliefs or religion alone or with others, in public or private, through "worship, teaching, practice, and observance." ${ }^{9}$ The European Convention also provides, however, that this seemingly broad right may be limited to protect "public order, health, or morals," or to protect the "rights and freedoms of others." 20 The French guarantee of religious freedom in the Law of 1905 follows this pattern, first broadly protecting the "liberty of conscience" and the "free exercise of religion," then narrowing this protection by subordinating it to the state's interest in maintaining public order, and further specifying that the state does not remunerate or subsidize religious activity. ${ }^{21}$

The religious exemption doctrine in the United States was consistent with this syntax. As I have indicated, from 1963 until it abandoned the exemption doctrine in Smith in 1990, the United States Supreme Court construed the Free Exercise Clause as providing that a law that interfered with a religious belief or practice

17. See infra Part III.

18. See infra Part IV.

19. Convention for the Protection of Human Rights and Fundamental Freedoms art. 9, Nov. 4 1950, 213 U.N.T.S. 222, 230.

20. Id.

21. Loi du 9 Décembre 1905 [Law of Dec. 9, 1905] arts. 1, 2, available at www.legifrance.gouv.fr/ texteconsolide/MCEBW.htm; see also Declaration of the Rights of Man and the Citizen art. 10, Aug. 26, 1789, available at http://www.yale.edu/lawweb/avalon/rightsof.htm. 
violated the free exercise of religion, unless the government could show that the law protected a particularly important regulatory interest in the least restrictive or intrusive manner. The justification required of the government under the exemption doctrine, however, was more restrictive than the limitations clauses that characterize the French Law of 1905 and the European Convention.

The Smith doctrine of formal neutrality, on the other hand, is not easily stated in this grammar. Freedom of religion after $S$ mith is less a liberty right than an equality right - a formal equality right. To say that the Free Exercise Clause protects only against government action that intentionally burdens religious liberty, as Smith does, means that in terms of "limitations," the law in the United States is that religious activity generally may be limited for any reason other than antireligious animus. Although this appears to leave freedom of religion fully exposed to government insensitivity or indifference to incidental burdens that its actions may impose on religion, I shall explain how the equality-shaped contours of constitutional doctrine in the United States buffer religious beliefs and practices from such burdens by enabling believers in many circumstances to claim the same protection as that afforded by government to the beliefs and practices of those committed to secular ideologies and moralities. ${ }^{22}$

\section{Sociology of Religion in the United States and France}

\section{A. American Spirituality}

One of the most important developments in recent decades in the United States has been the growth of an individualized, extradenominational interest in religion that is usually referred to as "spirituality." In a monograph provocatively entitled Spiritual, but not Religious, Robert Fuller defines spirituality as the attitude of one struggling to understand how his or her life relates to a greater cosmic scheme. ${ }^{23}$ According to Fuller, "[w]e encounter spiritual issues every time we wonder where the universe comes from, why we are here, or what happens when we die," as well as when we are "moved by values such as beauty, love, or creativity that seem to reveal a meaning or power beyond our visible world." 4 "An idea or practice is 'spiritual,"” argues Fuller, "when it reveals our personal

22. See infra Part III.

23. Robert C. Fuller, Spiritual, but not Religious 8 (2001).

24. Id. at $8-9$. 
desire to establish a felt-relationship with the deepest meanings or powers governing life." 25

"Spirituality" captures the religious stance of the increasing number of Americans who practice religion outside of the teachings and doctrines of a traditional denomination. ${ }^{26}$ Many such believers see the catechisms and other theological boundaries of denominational religion as obstacles to their personal quests for meaning in life. ${ }^{27}$ As Fuller suggests, they describe themselves as "spiritual," but not "religious." ${ }^{28}$ Fuller estimates that as many as one in five Americans currently fit this description, ${ }^{29}$ with the number steadily increasing. If accurate, this estimate would mean that there are nearly as many spiritually unchurched people in the United States as there are members of any single denomination. ${ }^{30}$

The influence of the new spirituality is not confined to the unchurched, but has reached into denominational religion to alter the relationship of members to their churches. Those who retain a denominational affiliation are increasingly shifting their religious commitment away from strict adherence to the beliefs and practices of their denomination, in the direction of personal spirituality. ${ }^{31}$ Religion has become, in a word, "consumerized." 22 Many religious Americans now "shop"

\section{Id. at 9.}

26. See, e.g., Peter L. Berger, Reflections on the Sociology of Religion Today, 62 Soc. ReLIGIon 443, $446-47$ (2001) (noting the "declining number of people who profess traditional religious beliefs," and who define and practice "their religiosity in non-traditional, individualized and institutionally loose ways"); Charles Trueheart, Welcome to the Next Church, The AtLantic Monthly, Aug. 1996, at 37 (describing contemporary American churches that have wholly abandoned the traditional Christian denominational forms of worship).

27. Fuller, supra note 23 , at 4.

28. FULLER, supra note 23, at 4; accord Berger, supra note 26, at 448.

29. Fuller, supra note 23 , at 5 .

30. Alan Wolfe, The Transformation of American Religion: How We Actually live OUR FaITH 183 (2003).

31. See Fuller, supra note 23, at 9.

32. See Frederick Mark Gedicks \& Roger Hendrix, Religious Experience in the Age of Digital Reproduction, 79 ST. JohN's L. Rev. 127, 157 (2005) (noting the "consumerization of religion and religious experience" enabled by digitization and postmodernism); $C_{\text {Harles }} \mathrm{T}_{\text {aYlor, }} \mathrm{V}_{\text {ARIETIEs of }}$ Relicion TODAy 102-03 (2002) (noting that in the United States, the consumerization of religion resonates with the general consumer culture that developed in the wake of the dramatic growth of economic well-being in the latter half of the twentieth century); Martin Marty, The Widening Gyres of Religion and Law, 45 DePAUL L. Rev. 651, 664 (1996) (noting the "postmodern approach in organized religion, where the chaos of the marketplace and the 'picking and choosing' of religions have prevailed"). 
for a church to attend like they do for consumer goods, choosing one because of the individual needs and preferences that it satisfies, rather than the truth of the doctrines it teaches..$^{33}$ A related and growing phenomenon is so-called "cafeteria" or "grocery-cart" religion, in which one picks and chooses which of the doctrines and practices of a denomination one will observe, assembling a bricolage of beliefs and practices from among the teachings and doctrines of diverse and antagonistic denominations and traditions. ${ }^{34}$ Charles Taylor has succinctly captured this bewildering growth of "intermediate positions" between atheism and orthodox belief in the United States and other Western nations:

[M|any people drop out of active practice while still declaring themselves as belonging to some confession or believing in God. On another dimension, ... a wider range of people express religious beliefs that move outside Christian orthodoxy. Following in this line is the growth of non-Christian religions, particularly those originating in the Orient, and the proliferation of New Age modes of practice, of views that bridge the humanist/spiritual boundary, of practices that link spirituality and therapy. On top of this, more and more people adopt what would earlier have been seen as untenable positions; for example, they consider themselves Catholic while not accepting many crucial dogmas, or they combine Christianity with Buddhism, or they pray while not being certain they believe. ${ }^{35}$

The traditional denominational church "held and dispensed the 'means of grace' through which the individual might attain salvation, and without which that salvation was in jeopardy. ${ }^{36}$ One of the principal tasks of the traditional denomination was to police the conformity of parishioners to the behavioral and creedal requirements of membership, and to certify the good standing before God of those members who comply with these requirements. ${ }^{37}$ In the contemporary church, however, "the individual is the focus and exerciser of power"; indi-

33. Rebecca French, Shopping for Religion: The Change in Everyday Religious Practice and Its Importance to the Law, 51 Buff. L. Rev. 127, 164-65 (2003). See generally Trueheart, supra note 26.

34. French, supra note 33, at 165-66; Berger, supra note 26, at 448.

35. TAYLOR, supra note 32 , at 106-07.

36. Barbara Hargrove, The Sociology of Religion 128 (1979).

37. See id. at 128. 
viduals judge their religion on the basis of whether it helps them to understand and discover themselves in the midst of the demands of their everyday life, rather than whether its teachings and doctrines conform to an external and ultimate divine reality. ${ }^{38}$

\section{B. Doctrinal Imperatives of Spirituality}

Religious nondiscrimination is the only plausible understanding of what the Free Exercise Clause can require in a religiously plural postmodern United States marked by growing interest in spirituality and declining interest in traditional denominational religion. Denominational religion made the religious exemption doctrine plausible. Only when the definition of religion is strictly confined within clear boundaries can the state safely excuse citizens and others from obeying the law on the basis of religious beliefs or practices. Without a relatively narrow definition of religion, the effect of the exemption doctrine is to excuse unacceptably large numbers of people from complying with unacceptably large numbers of laws. As the Supreme Court observed in Smith, allowing religious belief to excuse the violation of law "would be to make the professed doctrines of religious belief superior to the law of the land, and in effect to permit every citizen to become a law unto himself." 39 The broader the definition of religion, the larger the potential number of people that might be excused from obeying the law.

The unworkability of the exemption doctrine, and the inevitability of its replacement by formal neutrality and religious nondiscrimination, were evident almost as soon as the Court adopted the exemption doctrine in the 1960s. The first of the Draft Exemption Cases involved a university student who sought exemption from the draft, not on the basis of the teachings of a denominational re-

38. 1d. Again, Taylor suggests that the self-oriented character of spirituality is the result of a long series of developments in Western history. TAYLOR, supra note 32, at 8-13.

39. Employment Div. v. Smith, 494 U.S. 872, 879 (1990) (quoting Reynolds v. United States, 98 U.S. 145, 166-67 (1879)); see also Christopher L. Eisgruber \& Lawrence G. Sager, The Vulnerability of Conscience: The Constitutional Basis for Protecting Religious Conduct, 61 U. CHI. L. Rev. 1245, 1256 (1994) (arguing that "idiosyncracies [sic] in the welfare functions of some individuals will support extreme and intuitively discreditable demands on social resources on their behalf," yet "[r]eligious belief need not be founded in reason, guided by reason, or governed in any way by the reasonable. Accordingly, the demands that religions place on the faithful, and the demands that the faithful can in turn place on society in the name of unimpaired flourishing, are potentially extravagant."). 
ligion or any conventionally religious beliefs of his own that war is morally wrong but rather on the basis of a personal morality that he derived from personal study of mostly secular philosophy. ${ }^{+0}$

In the world of the American framers, to be morally and conscientiously opposed to war was to be religiously opposed to war, almost by definition, since in the United States of the late-eighteenth century agnostic or areligious systems of morality were barely conceivable. By the 1960s, however, it could hardly be doubted that one could be a moral and conscientious pacifist without believing in God or adhering to any religious tradition whatever. As the Supreme Court recognized, it would have been deeply unjust in this social context to limit conscientious draft exemptions to members of denominational religions that teach the immorality of war. Accordingly, the Court expanded the statutory definition of religious belief beyond its conventional meaning to encompass a person's " $u$ ultimate concern," or that which a person takes "'seriously, without any reservation." +1 While this expanded definition avoided injustice, it threatened the efficient operation of the military draft, by greatly expanding the pool of potential conscientious objectors to include those whose opposition to war, though morally founded, was entirely secular. ${ }^{42}$

A similar dynamic affected the Court's decisions in two cases involving the Amish in the 1970s and 1980s. ${ }^{43}$ The Amish are a small anabaptist sect that seeks to live according to the simplicity of preindustrial times, eschewing the use of most modern machines, appliances, and communications, and retaining an oldfashioned style of dress and social interaction. In the first of these cases, the Amish sought to have their children excused from attending public high school as required by compulsory school-attendance laws, claiming that such attendance had

40. United States v. Seeger, 380 U.S. 163, 166-67 (1965).

41. Id. at 187 (quoting Paul Tillich, The Shaking of the Foundations 57 (1948)); accord Welsh v. United States, 398 U.S. 333, 339-40 (1970) ("What is necessary under Seeger for a registrant's conscientious objection to all war to be 'religious' within the meaning of $\S 6(j)$ is that this opposition to war stem from the registrant's moral, ethical, or religious beliefs about what is right and wrong and that these beliefs be held with the strength of traditional religious convictions."); see also Marty, supra note 32, at 666 (observing that the "tradition that saw religion dealing always with a Supreme Being" is "thinned out" in Seeger and Welsh).

42. See Gillette v. United States, 401 U.S. 437, 455 (1971) (“Apart from the Government's need for manpower, perhaps the central interest involved in the administration of conscription laws is the interest in maintaining a fair system for determining who serves when not all serve.") (internal quotation marks omitted).

43. United States v. Lee, 455 U.S. 252 (1982); Wisconsin v. Yoder, 406 U.S. 205 (1972). 
a corrosive effect on the Amish religious community. ${ }^{+1}$ Though it was sympathetic to this claim, the Court nevertheless feared that many other groups-especially counter-cultural "hippy" communes-might also seek to be excused from schoolattendance laws. ${ }^{45}$ As the Court stated, "[T] he very concept of ordered liberty precludes allowing every person to make his own standards on matters of conduct in which society as a whole has important interests." ${ }^{\text {t6 }}$ Though the Court did indeed grant the Amish an exemption, it wrote its opinion so narrowly that it was difficult to see how anyone but the Amish could qualify for it. ${ }^{47}$

A decade later, the Amish sought exemption not from the burden of compulsory school-attendance laws but from that of paying social security selfemployment taxes. Here the Supreme Court recognized the potential avalanche of exemption claims from others that would follow a decision granting the Amish exemption from paying taxes, ${ }^{48}$ and denied exemption to the Amish. ${ }^{49}$

The Draft Cases and the Amish Cases capture the dilemma of an exemption regime in a world of broad religious and moral difference, in which secular commitments have the same moral status as religious commitments, and in which it is common for individuals to manufacture their own idiosyncratic religions without the discipline of denominational boundaries: To avoid inequality and unfairness, exemptions must be extended beyond the traditional denominations to those with unusual religious beliefs, as well as to those whose beliefs are based upon secular morality. Yet, to extend the reach of exemptions so far would seriously undermine the observance, and thus the effectiveness, of law.

\footnotetext{
44. E.g., Yoder, 406 U.S. at 218.

45. See, e.g., id. at 215-16.

46. Id.
}

47. See id. at 235-36 (emphasizing that the Court was "not dealing with a way of life and mode of education by a group claiming to have recently discovered some 'progressive' or more enlightened process for rearing children for modern life," and observing that "a history of three centuries as an identifiable religious sect and a long history as a successful and self-sufficient segment of American society" had enabled the Amish to make a "convincing showing" that "few other religious groups or sects could make" of the "sincerity of their religious beliefs," the "hazards presented by the State's enforcement" of the disputed statute, and the adequacy of the informal vocational training associated with Amish life as a substitute for compulsory high school education); Robert G. McCloskey, The American Supreme Court 238 (4th ed. 2005) (observing that the Court was "careful to limit its decision [in Yoder] to groups like the Amish, with their centuries-long history and general record of good behavior").

48. See Lee, 455 U.S. at 259-60 ("[I]t would be difficult to accommodate the comprehensive social security system with myriad exceptions flowing from a wide variety of religious beliefs.").

49. See id. at 261 . 


\section{French Parallels}

The problems of religious difference and idiosyncratic spirituality have their parallels in France. Professor Baubérot, for example, has observed the widespread sympathy for Buddhism in France, especially among the young, and notes that many such sympathizers integrate "elements of Buddhism into a personal religious identity which fuses different traditions." ${ }^{50} \mathrm{He}$ also refers to the emergence of "a new type of religious individualism" in France, according to which "each person invents ... a personal spiritual itinerary with sole reference to herself." $"$ All this, of course, is to say nothing of Islam, now the second largest religion in France, approaching 10 percent of the population. ${ }^{52}$

The French reaction to pluralism and immigration has been quite different from that of the United States. Rather than retreating to formal neutrality or some other doctrinal principle that avoids the need to distinguish among religions, the reaction of France has been precisely to develop such distinctions. Thus, in the French jurisprudence of religious freedom there is an express distinction between the religion and the sect, with the implication that the sect is threatening to public order and thus properly subject to special government controls and regulations. Similarly, though Islam is obviously not a sect, at the heart of the headscarf controversy is the disquieting sense that, with Islam, "something foreign and non-French has infiltrated" French society, ${ }^{53}$ refusing to assimilate and adopt secular, French republican values, like laïcité. ${ }^{54}$ As many have observed, this fear of immigrant subversion of French values to religious values was a persistent theme of the Stasi Commission. ${ }^{55}$ In France, diversity is not the unalloyed good that it often seems to be in the United States, and this is clearly reflected in France's rejection of the formal neutrality that the United States has embraced as a governing principle of free exercise doctrine.

50. See Baubérot, supra note 11 , at 450.

51. Id. at 453; see also Jacques Robert, Religious Liberty and French Secularism, 2003 BYU L. Rev. 637,652 (2003) (describing as one of the "major currents underllyingl public opinion" in France "the evolution of science and faith," leading "to a sort of 'deregularization' of all beliefs and to transfers and migrations heavy with amalgamations and derivatives" of religion).

52. See Baubérot, supra note 11, at 450; Robert, supra note 51, at 655-56.

53. Gunn, supra note 11 , at 456-57.

54. See Lesan, supra note 10, at 43 (noting "France's discomfort with its 5 million person [Islamic] minority and this population's hesitation to wholeheartedly adopt a French heritage").

55. See, e.g., id. at 23-24. 
Religious Exemptions, Formal Neutrality, and Lä̈cité 485

\section{III.Free Exercise Doctrine in the United States and France}

\section{A. The American Doctrines of Religious Neutrality and General Applicability}

The central element of the formal neutrality adopted by the Supreme Court in the Smith doctrine is a general rule of deference to government action that incidentally burdens religious beliefs or practices. Religiously neutral and generally applicable laws that incidentally burden religious exercise are subject to minimal judicial scrutiny under the Free Exercise Clause. Only when a law lacks religious neutrality or general applicability is it subject to "strict" or heightened judicial scrutiny. ${ }^{56}$

A law lacks religious neutrality if its text or purpose discriminates against religion - that is, if it restricts religious practices because they are religious. ${ }^{57}$ As I have explained, a law is formally neutral with respect to religion if it does not use religion as a basis of classification-that is, if the religious beliefs and practices of those to whom a law applies are irrelevant to the law's goals. Religious discrimination may be evident from the text of the law, ${ }^{58}$ as well as from its effect. ${ }^{59}$

Religious neutrality presupposes that the purpose of the Free Exercise Clause is to prevent religious discrimination, rather than to protect freedom of action in a domain of religious liberty. General applicability is an additional prohibition on religious discrimination which prohibits laws that pursue secular ob-

56. Church of the Lukumi Babalu Aye, Inc. v. City of Hialeah, 508 U.S. 520, 531-32, 546 (1993); Employment Div. v. Smith, 494 U.S. 872, 877-80, 882, 884-85 (1990).

57. Lukumi, 508 U.S. at 533.

58. Id. ("TThe minimum requirement of neutrality is that a law not discriminate on its face. A law lacks facial neutrality if it refers to a religious practice without a secular meaning discernable from the language or context.").

59. Id. at 534-35 ("Official action that targets religious conduct for distinctive treatment cannot be shielded by mere compliance with the requirement of facial neutrality. . . Apart from the text, the effect of a law in its real operation is strong evidence of its object."). For example, the Court noted that use of words like "sacrifice" and "ritual" in the ordinances, id. at 534, as well as the recital in these laws that they were intended to prohibit religions engaging in particular practices contrary to "public morals, peace or safety," id. at 535, were evidence that the texts of the ordinances were not religiously neutral. The Court also counted as evidence of lack of religious neutrality that virtually the only conduct the ordinances prohibited was the worship rituals of the Santeria. Id. at 535-36. For example, although the ordinances purported to regulate the unnecessary and inhumane killing of animals, hunting and fishing for sport, using rabbits to train greyhound racing dogs, and kosher slaughter by severance of the carotid arteries were all exempt from the prohibitions of the ordinances. Id. at 535-37. 
jectives only against religious conduct. ${ }^{60}$ A generally applicable law is one that does not focus its burdens or benefits on a particular religious class to the exclusion of secular classes that are similarly situated. ${ }^{61}$

Religious neutrality and general applicability are mutually reinforcing tests: A law that religiously discriminates is usually not generally applicable, and a law that focuses its burdens entirely on religious persons and organizations is usually not religiously neutral. ${ }^{62}$ Consider, for example, a police force grooming standard which purports to prohibit officers from wearing beards, in order to promote a clean-cut image and to develop esprit de corps among officers. ${ }^{63}$ Assume that the police force refuses to exempt from this standard Muslim, Sikh, and other officers who wear beards for religious reasons, but that it routinely exempts any officer who wears a beard because he suffers from a skin condition; because, say, he wishes to keep his face warmer during the winter; because he is portraying Santa Claus in a local Christmas play; because he wishes to look older and more distinguished; or, indeed, because of any reason other than religious conscience. ${ }^{64}$ Even if the standard is somehow worded so that it does not by its terms classify on the basis of religion, its effect is still to prevent police officers from wearing beards only when they are worn for religious reasons. The standard thus lacks religious neutrality, because it singles out or targets religious conduct for a burden-the prohibition on wearing beards for religious reasons - that is not imposed on secular conduct-beards may be worn for any nonreligious reason. ${ }^{65}$

60. See, e.g., Lukumi, 508 U.S. at 524 (“[T]he principle of general applicability was violated because the secular ends asserted in defense of the [challenged] laws were pursued only with respect to conduct motivated by religious beliefs."); id. at 543 ("[G]overnment, in pursuit of legitimate interests, cannot in a selective manner impose burdens only on conduct motivated by religious belief ...."); id. at 545 ("[E]ach of Hialeah's ordinances pursues the city's governmental interests only against conduct motivated by religious belief. The ordinances 'ha[ve] every appearance of a prohibition that society is prepared to impose upon [Santeria worshipers] but not upon itself") (quoting and paraphrasing Florida Star v. B.J.F., 491 U.S. 524, 542 (1989) (Scalia, J., concurring in part and concurring in the judgment)).

61. See Lukumi, 508 U.S. at 543.

62. Id. at 531; see also Thomas v. Anchorage Equal Rights Comm'n, 165 F.3d 692, 701-02 (9th Cir. 1999), vacazed on ripeness grounds on rehearing en banc, 220 F.3d 1134 (9th Cir. 2000) ("Underinclusiveness is not in and of itself a talisman of constitutional infirmity; rather, it is significant only insofar as it indicates something more sinister," such as a government goal of "suppressing religious exercise.").

63. See Fraternal Order of Police Newark Lodge No. 12 v. City of Newark, 170 F.3d 359, 366 (3d Cir. 1999).

64. See id. at 360 .

65. See id. at 365 . 
The grooming standard also lacks general applicability. If one assumes that most police officers do not wear beards for religious reasons, then a grooming standard that prohibits beards only when they are worn for religious reasons does not apply to most of the police force.$^{66}$ In American constitutional jurisprudence, a law lacking general applicability is called "underinclusive," because "it applies to less than the entire universe of cases that pose the problem the law seeks to solve." ${ }^{67}$ The grooming standard is dramatically underinclusive, because it prohibits only a small portion of the conduct-wearing a beard-that purportedly undermines its image and officer-unity purposes.

Although the Supreme Court characterizes both religious neutrality and general applicability as tests that screen for religious discrimination, a broader reading of general applicability is possible. Consider a police grooming standard that prohibited all officer beards, except those worn for medical reasons. ${ }^{68}$ Such a policy might be justified on the dual grounds that those who suffer severe skin irritations from shaving can only comply with the standard by sacrificing their health, and that those officers availing themselves of the exception are likely to be a relatively small percentage of the force.

Of course, those who wear beards as a matter of religious belief can make comparable claims: Those who adhere to religions that require their male members to wear beards can only comply with the standard by abandoning this precept of their religion, and the number of officers wearing beards for religious reasons is likely to be a relatively small percentage of the force. From this, one can argue that the standard lacks general applicability because it is underinclusive with respect to its stated purposes - that is, it exempts some beards from the standard, thereby undermining its image and moral purposes, but refuses to exempt other beards that do not undermine these purposes to any greater extent than the exempted beards.

This broader reading of general applicability screens for a kind of religious discrimination that the narrow reading does not, what is sometimes referred to as "hostile indifference" to religion on the part of the government. ${ }^{69} \mathrm{~A}$ standard that prohibits all beards except those worn for medical reasons does not target only re-

66. Cf. id. at 367 (noting that the Muslim plaintiffs differed from most other members of the force in wishing to wear beards for religious reasons).

67. Michael W. McConnell et al., Religion and the Constitution 212 (2002).

68. Shaving reportedly causes severe acne and skin irritations in some men, particularly African Americans.

69. See Perry, supra note 6, at 300-02. 
ligious conduct, because substantial amounts of secular conduct-beards worn for warmth, costume, or personal preference-are prohibited along with religious conduct-beards worn for religious reasons. It thus does not violate the principle of religious neutrality. The standard nevertheless discriminates against religion, though in a more subtle way. Exempting secular activity from a law, but not religious activity, reflects a legislative determination that nonexempt religious activity is less important than the exempted secular activity. ${ }^{70}$ Put another way, the medical exemption reflects an implicit judgment that freedom of religious exercise is a less important personal interest than maintaining a clear complexion. Yet, religious activity is a "constitutionally preferred" liberty under the express protection of the Free Exercise Clause, whereas most secular activity reflects interests of no special constitutional significance. ${ }^{11}$ By exempting from the standard beards worn for medical reasons, but not beards worn for religious reasons, the grooming standard elevates the right to proper treatment of a medical condition, which is nowhere guaranteed by the U.S. Constitution, over the right to the free exercise of one's religion, which is expressly protected by the First Amendment.

Some commentators have argued that this broader reading of general applicability requires strict scrutiny of any law that provides for any secular exemptions, but no religious exemptions. ${ }^{72}$ This is not a reading that has been adopted by the Supreme Court, however. Although there are hints that the Court might be prepared to expand the meaning of general applicability in a proper case, ${ }^{73} \mathrm{re-}$

70. Eugene Volokh, A Common Law Model for Religious Exemptions, 46 UCLA L. Rev. 1465, 1541 (1999). Because he maintains that judgments about the extent to which religious activities are comparable to exempted secular activities are better made by legislatures than courts, Professor Volokh argues that laws which favor secular activities over apparently similar religious activities, by exempting the former but not the latter, are "perfectly proper." Id. at 1540-41.

71. Laycock, supra note 5, at 51; see also Note, Neutral Rules of General Applicability: Incidental Burdens on Religion, Speech, and Property, 115 HARv. L. Rev. 1713 (2002) (arguing that the Supreme Court now provides greater constitutional protection to private property rights than to free exercise rights).

72. See, e.g., Richard F. Duncan, Free Exercise is Dead, Long Live Free Exercise: Smith, Lukumi and the General Applicability Requirement, 3 U. PA. J. Const. L. 850 (2001).

73. See Church of the Lukumi Babalu Aye, Inc. v. City of Hialeah, 508 U.S. 520, 542 (1993) ("All laws are selective to some extent, but categories of selection are of paramount concern when a law has the incidental effect of burdening religious practice."); $i d$. at 543 ("The ordinances are underinclusive for those ends [of protecting public health and preventing animal cruelty]. They fail to prohibit nonreligious conduct that endangers these interests in a similar or greater degree than Santeria sacrifice does. The underinclusion is substantial, not inconsequential."); Employment Div. v. Smith, 494 U.S. 872, 884 (1990) (distinguishing Unemployment Compensation Cases because, inter alia, they did not involve "an across-the-board criminal prohibition on a particular form of conduct"). 


\section{Religious Exemptions, Formal Neutrality, and Lä̈Cité 489}

quiring that the government provide religious exemptions whenever a law allows any exemption for secular conduct would be to create an exception to the Smith doctrine that swallows up the general rule. ${ }^{74}$

A more realistic reading of general applicability would require the government to show that exempted secular conduct has a different relationship to the purpose of the law than nonexempted religious conduct. ${ }^{75}$ In other words, a religious exemption is required only when nonexempt religious conduct presents no greater threat to a law's purpose than already exempt secular conduct. ${ }^{76}$ To return yet again to the police officer grooming standard, suppose that the standard prohibits all officer beards for image and unity purposes, except those worn by undercover officers. Granting an exemption to the latter does not undermine these purposes, because undercover officers by definition have concealed their association with the police force and thus do not project any image at all on behalf of the police force. ${ }^{77}$ Similarly, because undercover officers do not interact with regular officers as part of the regular uniformed chain of command, their beards do not disrupt force unity to the same extent as beards worn by regular uniformed officers.

74. See MCCONNELL ET. AL., supra note 67, at 212 (suggesting that there is no difference between an exception to a law, and a simple lack of coverage by the law); Carol M. Kaplan, Note, The Devil Is in the Details: Neutrality, General Applicable Laws and Exceptions from Smith, 75 N.Y.U. L. Rev. 1045,1067 (2000) (arguing that a constitutional rule that mandated a religious exemption whenever a law allows any sort of secular exemption "clearly flies in the face of the holding in Smith"); Kenneth D. Sansom, Sharing the Burden: Exploring the Space Between Uniform and Specific Applicability in Current Free Exercise Jurisprudence, 77 TEx. L. REv. 753, 768 (1999) ("[O]ne can posit that a law which includes even a single secular departure, but does not match it with an equivalent accommodation departure is not generally applicable for the purposes of the Free Exercise Clause because it is underinclusive in that there is some secular conduct to which it does not apply. Lukumi does not, however, support such a simple decision.").

75. Frederick Mark Gedicks, The Normalized Free Exercise Clause: Three Abnormalities, 75 IND. L.J. 77, 119 (2000) [hereinafter Gedicks, The Normalized Free Exercise Clause]; see also Robert W. Tuttle, How Firm a Foundation? Protecting Religious Land Uses After Boerne, 68 Geo. Wash. L. Rev. 861, 888-90 (2000) (arguing for a similar conclusion based upon the heightened "hard-look" rational basis scrutiny of City of Cleburne v. Cleburne Living Center, 473 U.S. 432 (1985), in which the Court invalidated denial of a special use permit for a group home for the mentally retarded by rejecting purported distinctions between the home and other permitted uses).

76. Gedicks, The Normalized Free Exercise Clause, supra note 75, at 118-19; accord Sansom, supra note 74 , at 770 (arguing that a religious exemption from a law is appropriate under the General Applicability Exception when a secular exemption permitted by the law would "undermine the purpose of the law's general proscription or mandate," and allowing a religious exemption "would not undermine that purpose any more than the secular departure already does").

77. Fraternal Order of Police Newark Lodge No. 12 v. City of Newark, 170 F.3d 360, 366 (3d Cir. 1999). 
In sum, according to the Supreme Court a religiously neutral law does not fail the test of general applicability merely by being modestly or even substantially underinclusive; rather, the law must be so dramatically underinclusive that religious conduct is virtually the only conduct to which the law applies. The Court apparently will tolerate a substantial amount of underinclusion before finding that a law is not generally applicable, so long as the underinclusion stops short of actually targeting religious conduct. Whether the doctrinal hurdle represented by general applicability will be raised so far as to require heightened scrutiny of laws that exempt secular conduct but not similarly situated religious conduct, as suggested by some lower court decisions ${ }^{78}$ remains to be seen.

\section{B. Doctrinal Dimensions of Laïcité?}

As before, one can cite the French distinction between religions and sects as evidence of a lesser commitment to religious neutrality as a constitutional norm

78. See, e.g., Tenafly Eruv Assoc., Inc. v. Borough of Tenafly, 309 F.3d 144 (3d Cir 2002) (upholding injunction against enforcement of ordinance prohibiting signs on city-owned utility poles, as against Orthodox Jews who had used the poles to mark an eruv, on grounds that city had not enforced the ordinance to prevent display of some name and address signs and certain symbols on the poles); Fraternal Order of Police, 170 F.3d at 367 (holding that police department's refusal to exempt Muslim police officers from no-beard rule when rule provided for medical exemptions is subject to strict scrutiny, because "[ $w]$ e are at a loss to understand why religious exemptions threaten important city interests but medical exemptions do not"); Black Hawk v. Pennsylvania, 114 F. Supp. 2d 327, 331-32 (M.D. Pa. 2000) (holding that statute giving government authority to grant exemptions from provision requiring destruction of aggressive wild animals is subject to strict scrutiny); Keeler v. City Council, 940 F. Supp. 879 (D. Md.1996) (holding that application of historic preservation ordinance against church is subject to strict scrutiny when ordinance provided for exemptions in case of a "major improvement of benefit to the city," "financial hardship," or circumstances that would not be in the "interests of the city" or of "a majority of persons in the community," but did not provide for religious exemptions); Rader v. Johnston, 924 F. Supp. 1540, 1553 (D. Neb. 1996) (holding that refusal to exempt evangelical Christian from parietal rule requiring that freshman live in university housing is subject to strict scrutiny where "exceptions are granted ... for a variety of nonreligious reasons, [but] not granted for religious reasons," "[o]ver one third of the freshman students ... are not required to comply with the parietal rule," and there existed a system of individualized assessment which "refused to extend exceptions to freshman ... for religious reasons"); Horen v. Commonwealth, 479 S.E.2d 553, 557 (Va. Ct. App. 1997) (holding that government intent to discriminate against religion may be inferred from state law prohibiting possession of owl feathers, which exempted "taxidermists, academics, researchers, museums, and educational institutions," but not those who possess owl feathers for bona fide religious uses). But see Jackson v. District of Columbia, 89 F. Supp. 2 d 48 (D.C. Cir. 2000) (declining to apply general applicability analysis to underinclusive classifications burdening free exercise rights of incarcerated prisoners). 
governing the free exercise of religion. As I have mentioned, France has a welldeveloped jurisprudence surrounding the distinction between religions and sects. Such a distinction would be illegitimate in American constitutional jurisprudence, though it undeniably plays an informal role in shaping issues and decisions before some judicial and administrative decisionmakers.

The situation with general applicability is more complex. Although the policy relating to "ostentatious" religious clorhing and symbols in French public schools was triggered by the headscarf controversy and unquestionably aimed at Islam, by its terms it has a broader application. For example, the policy prohibits large Christian crosses and Jewish yarmulkes as well as headscarves, and it applies to ostentatious political symbols as well as religious ones. The un willingness to formulate a policy solely for Islam - which could not credibly be treated as a sect even under the French religion-sect distinction-or even solely for religious clothing and symbols, suggests the possibility that general applicability is a jurisprudential principle that could take root in the French doctrine of religious freedom.

More broadly, France has a powerful sensitivity to religions and sects that seem to threaten or undermine its concept of the republican citizen and the republican society. One senses that most of France is united in the commitment to protect republican values against such threats, even if such protection requires imposing special legal burdens on particular religions and sects that refuse to assimilate to the majority's understanding of French republicanism. Again, such a response to nontraditional religions is not part of formal doctrine in the United States. While one certainly hears in certain sectors of politics and the popular media the accusation that particular beliefs are "un-American," the idea that such "un-Americanism" might be legitimately and openly used as a predicate for legislation or regulation of religious exercise remains beyond the limits of legitimacy in American constitutional law.

\section{Conclusion}

Both of our countries can learn from each other. In the United States, the conception of liberty as the absence of government makes it convenient to forget that the withdrawal of government power will leave liberty in its wake only if there are no imbalances of private power. Where such imbalances exist, it may be the obligation of government to intervene, even at the cost of intrusion upon individual privacy and choice. This is the grim lesson of domestic violence, which was sheltered for generations in the United States by a commitment to 
"familial privacy." It may also be the lesson of the current church abuse cases, in which it has become evident that sexually predatory clergy in the United States were sheltered in their crimes by an excessive constitutional commitment to church autonomy. Formal neutrality mitigates the consequences of such a withdrawal, by authorizing government to regulate religious people when they pose the same secular threat as everyone else.

In France, where it is common to think of individual liberties as being achieved through the state, rather than in opposition to it, the risks of constitutional privacy and regulatory withdrawal are more obvious. Again, one can see this in the report of the Stasi Commission, which was concerned that if headscarves were not banned in public schools, many Islamic school girls would be forced against their will by parents and co-religionists to wear headscarves and otherwise to observe the strictly constrained female roles set out by fundamentalist and certain conservative strains of Islam. The headscarf was thus interpreted by the Commission as a symbol of the repression of women by fundamentalist Islam and other culturally conservative faiths, and banning the headscarf in public schools was understood as a vehicle of liberty, freeing girls from their religious and cultural bonds to assume the liberated life of a citizen of the Republic.

But there is a cost here, too. Women, even well-educated women who have financial resources and who are fully informed of their rights and options, do not always freely choose the life of the model republican citizen, or any other life that might be promoted by the state. Liberty includes the right to choose for oneself what to make of oneself. For women and others who find meaning, identity, and purpose in culturally conservative religions, the insistence of the state that they assimilate to the secular, republican values of laïcité forces them to make the cruel choice between religious fidelity and national loyalty. Those who cannot or will not abandon the bonds of faith withdraw from public life and discourse into greater cultural isolation, resentful, angry, and isolated, and are thus at greater risk of becoming true enemies of the Republic. Indeed, the estrangement of so many Muslims from the public life of France is commonly cited as a principal cause of the 2005 Muslim riots in the Paris suburbs. When weighed against the vivid costs of cultural isolation, formal neutrality, for all of its own risks and costs, may have something to offer constitutional jurisprudence in France. 